\title{
Estimation of Genetic Variability and Heritability for Seed Yield Characters in Greengram [Vigna radiata (L.) Wilczek]
}

\author{
S. Sanjupretham*, G. R. Lavanya and A. Sai Sri Vatsav \\ Department of Genetics and Plant Breeding, Naini Agricultural Institute, \\ Sam Higginbottom University of Agriculture, Technology and Sciences, \\ Prayagraj, Uttar Pradesh - 211007, India \\ *Corresponding author
}

\section{Keywords}

Greengram (Vigna radiate $\mathrm{L}.), \mathrm{GCV}$, PCV, Genetic variability, Heritability

\section{Article Info}

Accepted: 04 November 2019 Available Online: 10 December 2019

\section{A B S T R A C T}

The study was carried out on genetic Variability and heritability for seed yield characters in Mungbean [Vigna radiate (L.) Wilczek] for 13 characters of Mungbean on 25 genotypes including check (Samrat) were evaluated during Kharif, 2018 in Randomized Block Design. It was recorded that Harvest index, number of primary branches per plant, number of seeds per pod and number of pods per plant exhibited high PCV and GCV indicating the preponderance of additive gene action. Phenotypic correlation is higher than the genotypic correlation for the expression of these characters under study.

\section{Introduction}

Greengram [Vigna radiate (L.) wilczek] $(2 n=2 x=22)$ is third important pulse after chickpea and Pigeon pea. It is a self-pollinated crop and is an important grain legume of the tropical area. It belongs to the Family Fabaceae and Sub-family Papilionaceae. The centre of origin is India (Karpechenko, 1952)

Mungbean [Vigna radiate (L.) wilczek] is one of the predominant pulse crop because it consumes less water requirement, adaptation to soil fertility, short growth duration and due to easy digestibility low production of flatulance (Shil and Bandopadhya, 2007). The average protein content in the greengram seeds is around $24 \%$, which is comparatively high in lysine. Amino acid analysis indicates that the concentration of Sulphur containing Amino acids, namely Methionine and Cystine are low. It is widely cultivated throughout the Asia including India, Pakistan, Sri Lanka, Thailand, Cambodia, Bangladesh, Vietnam, Indonesia, Malaysia and South china.

Moreover, yield is a complex character and depends on number of component characters, 
which are quantitatively inherited. Integration of information on genetic variability, correlation, path analysis for seed yield characters and its component traits and their application in selection of superior segregants will be helpful in bringing varietal improvement in greengram. To recapitulate the present study on genetic variability on greengram was done.

\section{Materials and Methods}

The experimental material for present investigation was carried out during Kharif, 2018 at the Field Experimentation Centre of Department of Genetics and Plant Breeding, S.H.U.A.T.S., Prayagraj, situated in the "Middle Gangetic Plains" which falls under agro-climatic zone.

Twenty five genotypes of Greengram including check were evaluated following RBD with three replications. Five rows of each genotype in each replication with $1 \mathrm{~m}$ length, Row to Row and Plant to Plant distance was kept at $30 \mathrm{~cm}$ and $10 \mathrm{~cm}$, respectively

All the recommended cultural practices like thinning, weeding were carried out time to time throughout crop duration adopted to maintain a healthy crop growth...A basal dose of $20 \mathrm{~kg} \mathrm{~N}, 40 \mathrm{~kg}$ of $\mathrm{P}_{2} \mathrm{O}_{5} \mathrm{ha}^{-1}$ was applied.

Data regarding 13 attributing characters viz, days to $50 \%$ flowering, plant height $(\mathrm{cm})$, days to maturity, number of primary branches per plant, number of pods per plant, Number of clusters per plant, Pod length $(\mathrm{cm})$, Number of seeds per pod, Biological yield (g), Seed index (g), Harvest index (\%), Protein content $(\%)$, and Seed yield per plant were recorded for all the Mungbean genotypes. Genotypic coefficient of variation and phenotypic coefficient of variation (GCV and PCV) were calculated by the formula given by Burton, heritability in broad sense $\left(\mathrm{h}^{2}\right)$ by Burton and De Vane (1953) and genetic advance given by Jyothsna and Anuradha (2013).

\section{Results and Discussion}

Coefficient of variation provides a relative measure of variance among the different traits. Analysis of variance showed highly significant difference as revealed from ANOVA for all the characters in the study at $1 \%$ level of significance indicating Considerable amount of genetic variability among the genotypes in Table 1.

\section{Estimates of genetic parameters}

One of the salient considerations in any crop improvement is the comprehensive study of genetic variability. The efficiency of selection largely depends on the magnitude of genetic variability present in the plant population.

The favorable outcome of genetic improvement in any character depends on the value of variability for any character present in the gene pool for the component characters.

Hence assessment of existing variability for any character present in the gene pool of a species is almost important to a plant breeder for starting a wise plant breeding.

The estimates of variance, coefficient of variation, heritability and genetic advance for all the thirteen characters under study have been boxed in the Table 2 explained as under.

Genotypic Coefficient of Variation (GCV) and Phenotypic Coefficient of Variation (PCV)

The studies on GCV and PCV showed that the presence of high number of variation and role of the environment on the expression of these traits. The magnitude of PCV was higher than 
GCV for all the characters which may due to higher degree of interaction of genotype with the environment.

Variability is assorted as low if co-efficient of variation is less than (10\%), moderate (In between 10-20\%) and high (greater than 20\%) as proposed by Sivasubramaniam and Menon (1973). The estimates of PCV and GCV were revealed in Table 2.

The estimates of GCV revealed that it ranged from Days to maturity (3.71) to Harvest index (24.56).GCV estimates were highest for Harvest index (24.56) followed by number of primary branches per plant (23.68), Number of seeds per pod (20.69) and Number of pods per plant (20.68). Moderate magnitude of GCV were Number of clusters per plant (18.02), Biological yield per plant (17.57), plant height (14.33), Seed yield per plant (12.14) and pod length (10.35). Whereas, low magnitude $\mathrm{f}$ GCV were recorded for protein content (9.95), Seed index (7.29), Days to 50\% flowering (4.40) and days to maturity (3.71).

The estimates of PCV revealed for all the traits ranged from Days to maturity (3.93)to Harvest index (25.19). PCV estimates were highest for Harvest index (25.19) followed by Number of primary branches per plant (24.64), Number of pods per plant (23.24) and number of seeds per pod (22.49).

Moderate magnitude of Phenotypic Coefficient of Variation (PCV) were recorded for number of clusters of per plant (19.06), biological yield per plant (18.53), plant height (15.87), seed yield per plant (13.18), pod length (11.34) and protein content (10.36), whereas the magnitude of Phenotypic Coefficient of Variation (PCV) were recorded low for seed index (8.05), days to $50 \%$ flowering (4.61) and days to maturity (3.93).).High and moderate values of Phenotypic Coefficient of Variation were indicating the presence of high amount of variation in these traits. Reddy et al., (2014), observed moderate PCV for number of seeds per pod and plant height. High PCV for number of clusters was also observed by Lavanya (2006).

Higher magnitude of PCV and GCV were recorded for Harvest index followed by Number of primary branches per plant, Number of pods per plant and number of seeds per pod. Similar finding for variance and its components were reported by Patel et al., (2014), Hemavathyet al., (2015), Bhutia et al., (2016) and Shiv et al., (2017).

\section{Heritability and genetic advance}

Burton (1953) suggested the genetic variation along with heritability estimates would give better idea about the expected efficiency of selection thus a character possessing high GCV along the high heritability will be valuable in selection programme. In general the highest heritability estimates in broad sense was registered for all the characters understudy. The estimates of heritability for all 13 characters are presented in Table 2.

The heritability estimates varied from 79.14 (number of pods per plant) to 95.11 (harvest index). All the characters viz, days to $50 \%$ flowering (91.27), days to maturity (88.94), plant height (81.57), number of primary branches per plant (92.35), number of clusters per plant (89.39), number of pods per plant (79.14), number of seeds per pod (84.58), pod length (83.38), seed index (81.89), biological yield (89.90), harvest index (95.11), seed yield per plant (84.75) and protein content (92.38) were identified with high heritability. High heritability of these traits indicates that there is a close correspondence between the genotype and phenotype and selection can be done for these characters. Hemavathy et al.,(2015). 
Table.1 Analysis of variance for 13 seed yield characters of Greengram

\begin{tabular}{|c|c|c|c|}
\hline \multirow{2}{*}{ Characters } & \multicolumn{3}{|c|}{ Mean Sum of Squares } \\
\cline { 2 - 4 } & Replications & Treatments & Error \\
\cline { 2 - 4 } & $(\mathrm{df}=2)$ & $(\mathrm{df}=24)$ & $(\mathrm{df}=48)$ \\
\hline Days to 50\% flowering & 0.0104 & $11.1230^{* *}$ & 0.3437 \\
\hline Days to maturity & 0.006 & $294.378^{* *}$ & 0.756 \\
\hline Plant height & 21.730 & $2.070^{* *}$ & 20.610 \\
\hline $\begin{array}{c}\text { Number of primary branches } \\
\text { per plant }\end{array}$ & 0.090 & 0.056 \\
\hline Number of clusters per plant & 0.480 & $34.833^{* *}$ & 2.813 \\
\hline Number of pods per plant & 0.004 & $3.026^{*}$ & 0.115 \\
\hline Number of seeds per pod & 0.012 & $1.820^{* *}$ & 0.113 \\
\hline Pod length & 4.119 & $20.556^{* *}$ & 1.177 \\
\hline Seed index & 1.809 & $25.794^{* *}$ & 0.931 \\
\hline Biological yield & 0.014 & $0.165^{*}$ & 0.011 \\
\hline Harvest index & 5.199 & $262.887^{* *}$ & 4.432 \\
\hline Seed yield per plant & 0.699 & $12.548^{* *}$ & 0.336 \\
\hline Protein content & 0.0970 & $1.679^{*}$ & 0.095 \\
\hline
\end{tabular}

* and ** indicates significant at $5 \%$ and $1 \%$ level of significance

Table.2 Estimation of Genetic parameters of 25 greengram genotypes for 13 seed yield characters

\begin{tabular}{|c|c|c|c|c|c|c|}
\hline S. No. & Characters & $\begin{array}{c}\text { Genotypic } \\
\text { coefficient of } \\
\text { variation }(\mathrm{GCV})\end{array}$ & $\begin{array}{l}\text { Phenotypic } \\
\text { coefficient of } \\
\text { variation } \\
(\text { PCV })\end{array}$ & $\begin{array}{l}\text { Heritability } \\
(\%) \\
\text { (Broad sense) }\end{array}$ & $\begin{array}{l}\text { Genetic } \\
\text { advance } \\
\text { (GA) }\end{array}$ & $\begin{array}{c}\text { Genetic } \\
\text { advance as \% } \\
\text { of mean }\end{array}$ \\
\hline 1 & $\begin{array}{l}\text { Days to } 50 \% \\
\text { flowering }\end{array}$ & 4.40 & 4.61 & 91.27 & 3.73 & 8.66 \\
\hline 2 & Days to maturity & 3.71 & 3.93 & 88.94 & 4.79 & 7.21 \\
\hline 3 & Plant height & 14.33 & 15.87 & 81.57 & 17.77 & 26.66 \\
\hline 4 & $\begin{array}{l}\text { Number of primary } \\
\text { branches per plant }\end{array}$ & 23.68 & 24.64 & 92.35 & 1.63 & 46.87 \\
\hline 5 & $\begin{array}{l}\text { Number of clusters } \\
\text { per plant }\end{array}$ & 20.68 & 23.24 & 79.14 & 5.99 & 37.89 \\
\hline 6 & $\begin{array}{c}\text { Number of pods per } \\
\text { plant }\end{array}$ & 18.02 & 19.06 & 89.39 & 1.92 & 35.09 \\
\hline 7 & $\begin{array}{l}\text { Number of seeds per } \\
\text { pod }\end{array}$ & 10.35 & 11.34 & 83.38 & 1.42 & 19.48 \\
\hline 8 & Pod length & 20.69 & 22.49 & 84.58 & 4.82 & 39.19 \\
\hline 9 & Seed index & 17.57 & 18.53 & 89.90 & 5.62 & 34.31 \\
\hline 10 & Biological yield & 7.29 & 8.05 & 81.89 & 0.42 & 13.58 \\
\hline 12 & Harvest index & 24.56 & 25.19 & 95.11 & 18.65 & 49.35 \\
\hline 11 & Seed yield per plant & 9.95 & 10.36 & 92.38 & 3.99 & 19.71 \\
\hline 13 & Protein content & 12.14 & 13.18 & 84.75 & 1.38 & 23.02 \\
\hline
\end{tabular}


The estimate of genetic advance ranged from 18.65 (harvest index) to seed index (0.42), whereas it is high for plant height (17.77). Moderate genetic advance was recorded number of pods per plant (5.99), biological yield per plant (5.62), number of seeds per pod (4.82), days to maturity (4.79), protein content (3.99), days to $50 \%$ flowering (3.73), number of clusters per plant (1.92), number of primary branches per plant (1.63), pod length (1.42) and seed yield per plant (1.38) and low genetic advance was recorded for seed index (0.42).

The genetic advance as percent of mean ranged from 7.21 (days to maturity) to 49.35 (harvest index).

The high genetic advance as percent of mean recorded for number of primary branches per plant (46.87), number of seeds per pod (39.19), number of pods per plant (37.89), number of clusters per plant (35.09), plant height (26.66), seed yield per plant (23.02).

Moderate genetic advance as percent of mean was recorded for protein content (19.71), pod length (19.48) and seed index (13.58). Low genetic advance as percent of mean was recorded for days to $50 \%$ flowering (8.66) and days to maturity (7.21).

The estimates of high heritability coupled with high genetic advance as percent of mean was observed for harvest index $(95.11,49.35)$, Number of primary branches per plant (92.35, 46.87), Number of seeds per pod (84.58, 39.19), Number of pods per plant (79.17, 37.89), Number of clusters per plant (89.39, 35.09), Biological yield per plant (89.90, 34.31), Plant height $(81.57,26.66)$ and seed yield per plant $(84.75,23.02)$.

Whereas moderate heritability coupled with moderate genetic advance as percent of mean was observed for Protein content (92.38, 19.71), Pod length $(83.38,19.48)$ and Seed index $(81.89,13.58)$. High heritability coupled with low genetic advance as percent of mean was observed for Days to $50 \%$ flowering $(91.27,8.66)$ and Days to maturity (88.94, $7.21)$.

\section{References}

Anand, G., Anandhi, K. and Paulpandi, V.K. (2016). Genetic variability, correlation and path analysis for yield and yield components in $\mathrm{F}_{1}$ families of greengram [Vigna radiata (L.)Wilczek] under rainfed condition. Electronic Journal of Plant Breeding, 7(2): 434-437.

Bhutia, P., Lal, G.M. and Thomas, N. (2016). Studies on genetic variability, correlation and path analysis in greengram [Vigna radiata (L.)Wilczek] germplasm. International Journal of Agricultural Sciences. 2: 607-623.

Burton, G.W. and De Vane, E.M. (1953). Estimating heritability in tall fesses from replicated cloned material. Journal of Agronomy, 45(3):474-481.

Hemavaty, A.T., Shunmugavalli, N. and Anand, G. (2015). Genetic variability, correlation \&path coefficient studies on yield and its components in mungbean (Vigna radiate (L.)Wilczek). Legume Research, 38 (4):442-446.

Jyothsna, A.M. and Anuradha, C.H. (2013). Genetic variability, correlation and path analysis for yield and yield components in mungbean (Vigna radiata (L.) Wilczek). Journal of Research ANGRAU, 41(3): 31-39.

Kapadia, V.N., Raiyani, A.M. and Parmar, M.B. (2015).Genetic studies of variability correlation and path coefficient analysis for mungbean [Vigna radiata (L.) Wilczek] yield and its yield components. Trends in 
Biosciences. 8(5): 1270-1273.

Kapoor, R., Lavanya, G.R. and Suresh, B.G. (2005). Estimation of genetic variability in mungbean (Vigna radiate (L.) Wilczek). Journal of Food Legumes on Crops, 6(3): 509-510.

Lavanya, G.R. (2006). Evaluation of mungbean (Vigna radiata (L.)Wilczek) germplasm or genetic variability. Indian Journal of Plant Genetic Resource, 19(1): 104-10.

Rambabu V., G.R. lavanya, V. swarnalatha and T. Anuhyajayaprada. (2018) Genetic variability and character association for seed yield andits attributing traits in mungbean (Vigna radiate (L.) Wilczek). Journal Research. ANGRAU46(4) 25-31, 2018.

Reddy, R.N.B., Lad, D.B., and Mukhekar, G.D. (2005). Correlation and path analysis studies in greengram. Journal of Maharashtra Agriculture University, 30(2): 156159.

Sarkar, G., Panda, S. and Senapati, B.K. (2005). Genetic variability and characters association in mungbean [Vigna radiate (L.)Wilczek]. International Food Legumes Research Conference,
18-22 Oct, New Delhi.

Shiv, A., Vinita, R., Vadodariya, G.D., Modhas, K.J. and Patel, R.K. (2017). Genetic variability, Heritability and Genetic advance in F3 progenies of Mungbean (Vigna radiata (L.)Wilczek). International Journal of Current Microbiology and Sciences, 12: 3086-3094.

Singh, S.K., Singh, I.P., Singh, B.B. and Singh, O. (2009). Correlation and path coefficient studies for yield and its components in mungbean (Vigna radiate (L.) Wilczek). Legume Research, 32(3): 180-185.

Tabasum, A., Saleem, M. and Aziz, I. (2010). Genetic variability, trait association and path analysis of yield and yield components in mungbean [Vigna radiate (L.) Wilczek], Pakistan Journal of Botany, 42(6): 3915-3924.

Zaid, I. U., Khalil, I. H. and Sajid Khan.(2012). Genetic varibaility and correlation analysis for yield components in mungbean (Vigna radiata (L.) Wilezek). ARPN Journal of Agricultural and Biological Sciences, 7(11): 885-891.

\section{How to cite this article:}

Sanjupretham, S., G. R. Lavanya and Sai Sri Vatsav, A. 2019. Estimation of Genetic Variability and Heritability for Seed Yield Characters in Greengram [Vigna radiata (L.) Wilczek]. Int.J.Curr.Microbiol.App.Sci. 8(12): 77-82. doi: https://doi.org/10.20546/ijcmas.2019.812.012 